\author{
Review Article
}

\title{
ROLE OF NATUROPATHIC DIET IN PRENATAL PERIOD
}

\section{Malathi Syamala1*, Alugu Varshini2 $^{2}$, Santoshi Lakshmi ${ }^{3}$}

*1Senior Medical Officer, Nature cure Hospital, Director i/c, Ameerpet, Begumpet, Hyderabad.

${ }^{2}$ Secretary, Telangana Yogadhyana Parishad (TSYP), ${ }^{3}$ Assistant Professor, Dept. of Food \& Nutrition, OUCW, Hyderabad, Telangana.

\section{Article info \\ Article History: \\ Received: 27-06-2021 \\ Revised : 11-07-2021 \\ Accepted: 18-07-2021 \\ Published: 25-08-2021 \\ KEYWORDS \\ Vedic science, Satvik \\ diet, Upanishads, \\ prenatal period, \\ postnatal.}

\begin{abstract}
A healthy pregnancy is necessary to ensure the baby's well being after birth too. As per Vedic science the mother is the creator of child's future. This can be accomplished by adapting a Satvik diet during prenatal period. This approach helps her to builds a healthy future for her child. Yogis and ancient sages of India believed that Satvik food which means clean, pure and ethically energetic will maintain the equilibrium of a healthy mind and body. The origin of this diet has its roots in Indian ancient books like Upanishads, Bhagavatgida etc. The Ayurvedic texts also have insights regarding the diet for prenatal period which would help the woman to have healthy baby and safe post natal health. As per the ancient texts during the prenatal period the food should be simple, juicy and tasty. Foods which are stale, sour, bitter, fried salted and non-vegetarian origin those foods which have addiction should be avoided.
\end{abstract}

\section{INTRODUCTION}

Prenatal Nutrition is critical and will have an impact on the fetal growth, development of the baby and postnatal health of the women. During this period the woman has to eat for two. Healthy eating is always important for an expectant women, she must not cut down her calories or go on a diet. The optimum diet will promote the healthy body and mind while the inadequate diet may lead to disease. During prenatal period healthy diet can prevent the low birth weight, still births, excessive gestational weight and micronutrient deficiency.[1] The period of prenatal healthcare is considered as preventive healthcare.

In India much importance is given to the diet and its preparation, what they eat per meal and is considered as Brahma[2]. They believe that eating habits, methods of food processing and timely eating can result in sound body and mind. According to the Chandogya Upanishad, the majority of the food we eat will be divided into 3 parts. Major part of it will be rejected, second part help in building up the body while third part transforms into emotional thoughts, intellectual mind and memory sense, which is responsible for human values.[2]

\begin{tabular}{|l|l|}
\hline \multicolumn{3}{|c|}{ Access this article online } \\
\hline Quick Response Code & https://doi.org/10.47070/ijapr.v9i7.2004 \\
\hline & $\begin{array}{l}\text { Published by Mahadev Publications (Regd.) } \\
\text { publication licensed under a Creative } \\
\text { Commons Atribution-NonCommercial- } \\
\text { ShareAlike 4.0 International (CC BY-NC-SA } \\
\text { 4.0) }\end{array}$ \\
\hline
\end{tabular}

Indian yogis and saints stressed on the Yuktahara or Mithahara (appropriate or balanced diet). They say that journey of life begins with Annaamaya kosa i.e., sheath of food which surpasses to Ananda maya kosa i.e., sheath of bliss.[1]

In Bhagavadgita chapter $17-$ in $8^{\text {th }}, 9^{\text {th }}$ and $10^{\text {th }}$ Slokas, Lord Sri Krishna describes about Satva, Rajasa, and Tamasa gunas related to the diet.[3]

Satvik Diet: आयुःसत्त्वबलारोग्यसुखप्रीतिविवर्धना:| रस्या: स्तिर्धा: स्थिरा हृद्या आहारा:सात्त्विकप्रिया: || 8||

Āyuh-sattva-balārogya-sukha-prīti-vivardhanāḥ Rasyāḥ snigdhāḥ sthirā hridyā āhārāḥ sāttvika-priyāḥ

Persons in the mode of goodness prefer foods that promote the life span, and increase virtue, strength, health, happiness, and satisfaction. Such foods are juicy, succulent, nourishing, and naturally tasteful.

The foods like green leafy vegetables, all vegetables, freshly prepared foods, whole grains, cereals, milk after consuming one experience the lightness, energy, and inner consciousness are termed to be as Satvik foods.[3]

Rajisik Diet: कट्वम्ललवणात्युष्णतीक्षणरूक्षविदाहिनः| आहारा राजसस्येष्टा दुःखशोकामयप्रदा: ॥ 9॥

Kațv- amla- lavaṇāty- ușhṇa- Tīkșhṇa- rūkșhavidāhinaḥāhārā Rājasasyeșhțā duḥkha-śhokāmayapradāh.

Atv-amla-lavanaty-ushna- Tikshna-ruksha-vidahinah ahara Rajasasyeshta duhkha-shokamaya-pradah 
When Satvik foods are prepared with excess of salt, chilly, artificial sweeteners, sour and spicy becomes Rajisik while consuming increases the metabolism, stimulates nervous system, physical activity but not in a balanced form.

\section{Tamasik Diet: यातयामं गतरसं पूति पर्युषितं च यत्। उच्छिष्टमपि चामेध्यं भोजनं तामसप्रि||10॥}

Yāta-yāmaṁ Gata-rasaṁ pūti Paryușhitam cha Yatuchchhișhțam api Chāmedhyam் Bhojanam TāmasaPriyam

Foods that are overcooked, stale, putrid, polluted, impure, tinned, more acidic, remained more than 3 hours after cooking dear to persons in the mode of ignorance. (Tamasik) Consuming this kind of foods may results in sluggishness, produces the energy in destructive way.

Keeping this in view, Naturopathy, which is an age old system of practice of medicine is based on yogic principles of diet, adopts the month wise regime of Ayurvedic medicine and has devised the diet using the concept of Panchamahabhutas for prenatal period. It strongly believes the principles of Satvik ahara which influence on mind, effects on nervous system gives Chitanya shakthi [5].

Based on this, Naturopathy classified the diets as

1. Raw Diet: Which has high nutritive and low calorie producing foods such as fresh fruits, salads, dry fruits, sprouts etc.

2. Eliminative Diet: This diet is prescribed in conditions of detoxification and also to check the fluid balance. They give energy substantially. The eliminative diet consists of liquid diet i.e., citrus fruit juices, tender coconut water, thin buttermilk, etc.

3. Soothing Diet: When bodily system is recovering from any diseased condition, prefers this kind of diet. This diet is soothing to gut, easily palatable and digest. This must be consists of boiled vegetables, vegetable soups, buttermilk, semi solid alkaline porridges etc.

4. Constructive Diet: Helps in body building and increase the immunity. Consists of food prepared from cereals, whole grains, millets, pulses, sprouts, curd, nuts etc. ${ }^{[4]}$

\section{Role of Naturopathic Diet in Prenatal Nutrition:}

Good nutritious balanced diet i.e., consists of carbohydrates, proteins, fats, vitamins, minerals and fiber are required during the prenatal period will contribute to the proper fetal growth[6]. Month wise balanced nutrition is also required throughout the this period for proper constant growth of the embryo[7], nourishment of the mothers body to with stand labour and helps in production of breast milk. Thus diet plan must be prepared carefully to support the development of the fetus and to overcome the malnourishment or over nutrition conditions of the mother ${ }^{[8]}$. It can be suggested as below for the three trimester likewise

First Trimester: This to be considered from the time of conception to end of 12 weeks. During this period embryogenesis takes place. The formation of the brain, heart, spinal cord and lumps to form head, legs and hands are differentiated. Hence requires the energy producing foods which, helps in feotal fixation. [9]

Foods rich in folic acid, pyridoxine are suggested which helps in prevention of birth defects such as anencephaly, spina bifida and preeclampsia. These are available in legumes, leafy vegetables. As such in this period most of the women suffer from morning sickness, nausea, vomiting, headache, tiredness and backache. To overcome these symptoms naturopathy suggests a liquid diet and soothing diet like fresh fruit juices, thin buttermilk, coconut water, fresh properly boiled milk, vegetable soups, millets porridges with jaggery or honey as they are easily digested, gives the energy as per the need of the trimester, and helps in prevention of fat deposition.

Second Trimester: The period between 13th week to completion of 26th week. During this period all the organs are going to develop. As the fetus get stabilization mother feels heaviness in her body. Slowly the weight gain processes begins, mother experiences fetal movements. In this period Naturopathy suggests constructive diet rich in Proteins and Fat. Proteins are available in all varieties of lentils, dal preparations with leafy vegetables, legumes, soya, millets, sprouts as they are rich in antioxidants and numerous minerals helps in cell protection and tissue repairs, ghee i.e., a clarified butter, fats with omega 3 fatty acids helps in the fetal brain development. Fruits, all varieties of vegetables, leafy vegetables with dhal, milk and milk products help in the development of strong bones of the fetus. In this trimester most of the women suffer from constipation, pedal edema. Hence whole wheat preparations, fresh fruit juices, leafy vegetable soups, fiber fruits, often drinking of water are suggested. A whole wheat preparation relieves leg cramps and accumulation of water in legs, Barley water with honey is suggested till the symptoms disappear.

Third trimester: The period from $27^{\text {th }}$ week till the completion of $40^{\text {th }}$ week. In this trimester the overall development of the fetus would take place. Fetus responds to the expressions, facial movements, suckling of the fingers gets started. Fat accumulation takes place. A soothing and constructive diet is advised to regulate the weight gain. The foods like Wheat chapattis mixed with millet powder, aged rice, Food preparations with nut oils are recommended. Most of the women complaint about leg cramps during this period. Vegetable soups like methi, drumsticks, 
spinach can be advised. Ghee, rice milk, green gram, jaggery preparations are suggested as they are digested easily and helps in the motility of the intestines which in turn relieves the constipation. Seasonal fruits are recommended throughout the prenatal period as they help in providing the required vitamins, minerals like $\mathrm{Na}, \mathrm{K}, \mathrm{Mg}, \mathrm{Zn}, \mathrm{Fe}$, carotene, amino acids and fiber.[9]

The Naturopathy suggests that women in their prenatal period should remain away from Rajaisik and Tamasik ahahra such as spicy, hot, too cold or chilled foods, semi cooked, non pasteurized milk, preserved and packed foods, Alcohol, smoking, chewing tobacco and undue worry which may affect the physical, mental, and intellectual development of the fetus.

\section{CONCLUSION}

The Naturopathic treatment revolves around the concept of "prevention is better than cure". It promotes the health in positive manner, take out the disease from root cause. It believes that diet is medicine. It follows the diet principles suggested in Vedas and Upanishads. It emphasizes on Satvik diet. As explained in Vedas that diet right from the soiling to cooking and consuming with positive attitudes (Vicharas) develop the positive physical and mental health. As the Vedas and Puranas shows that a women during her pregnancy consumes the Satvik diet results in intellectual offsprings. This holistic diet helps in sustaining the overall growth, easy parturition and health of mother and baby. Apart from diet good exercises, exposing to sunlight, fresh air, timely rest also recommended in prenatal period. A healthy mother and a healthy baby make a healthy Nation.

\section{ACNOWLEDEMENT}

Dr.Rajyalakshmi, Supt Govt. Maternity Hospital Hyderabad.

\section{Cite this article as:}

Malathi Syamala, Alugu Varshini, Santoshi Lakshmi. Role of Naturopathic Diet in Prenatal Period. International Journal of Ayurveda and Pharma Research. 2021;9(7):71-73. https://doi.org/10.47070/ijapr.v9i7.2004

\section{Source of support: Nil, Conflict of interest: None Declared}

\section{REFERENCES}

1. Danielewicz H, Myszczyszyn G, Dębińska A, Myszkal A, Boznański A, Hirnle L. Diet in pregnancy-more than food. Eur J Pediatr. (2017); 176(12):1573-1579. doi:10.1007/S00431-0173026.

2. Sharma. B.R. Concept of Ahara (food) in Indian Perspective- An Analytical Study (2015), https:// www.esamskriti.com/e/Yoga/Texts/Concept-ofAhara-(Food)-In-Indian-Perspective- -AnAnalytical-Study-1.aspx

3. Swami Bramhanandaji, Chapter 17 Bhagvat Gita Chinmaya mission Chicago Badri school of Vedantic Studies

4. Rastogi R., (2017), Concept and role of diet as a component of NOPR. S 47 S 52. http://nopr. niscair.res.in $>$ bitstream

5. Jayanth Balaji athivale, Importance of a Sattvik diet. Sanatan Sanstha Publishers, Delhi.

6. Pooja, Bharadwaj \& Srivastava, Niraj \& Pradeep, Kumar \& Varsha, Saxena. (2020). Effect of Garbhini Ahara-Vihara (Diet \& lifestyle in pregnancy) on Garbhastha Sishu (Fetus) and offspring. International Journal of Research in Pharmaceutical Sciences. 11. 2802-2808. 10.26452 /ijrps.v11i3.2354.

7. Shital Rahul Rasane, Kirti Tushar Bhangale, (2016), Garbhini Paricharya according to various Samhita https://www.medpulse.in/Ayurveda/Article/Volu me1Issue1/Ayurveda_1_1_2.pdf

8. Reena Kulkarni, C Srilakshmi, M K Sarada (2020), Ayurveda principles of Garbhini paricharya (prenatal care) and its scientific relevance, $8: 1 \mathrm{Pp}$ : 5-9. DOI: 10.4103/JISM.JISM_24_20.

Disclaimer: IJAPR is solely owned by Mahadev Publications - dedicated to publish quality research, while every effort has been taken to verify the accuracy of the content published in our Journal. IJAPR cannot accept any responsibility or liability for the articles content which are published. The views expressed in articles by our contributing authors are not necessarily those of IJAPR editor or editorial board members. 